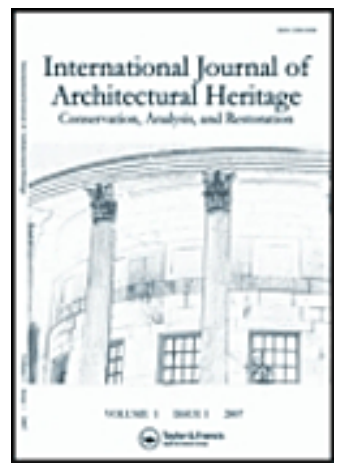

\title{
INTEGRATED GPR AND LASER VIBRATION SURVEYS TO PRESERVE PREHISTORICAL PAINTED CAVES: CUEVA PINTADA CASE STUDY
}

\begin{tabular}{|r|l|}
\hline Journal: & International Journal of Architectural Heritage \\
\hline Manuscript ID & UARC-2019-2492.R1 \\
\hline Manuscript Type: & Original Article \\
\hline Date Submitted by the & nuthor: \\
\hline Complete List of Authors: & $\begin{array}{l}\text { Caselles, Oriol; Universitat Politècnica de Catalunya, Ingeniería del } \\
\text { Terreno, Cartográfica y Geofísica } \\
\text { Clapés, Jaume; Universitat Politècnica de Catalunya, Ingeniería del } \\
\text { Terreno, Cartográfica y Geofísica } \\
\text { Rodríguez-Santana, Jose-Ignacio; Museo y Parque Arqueológico Cueva } \\
\text { Pintada (Cabildo de Gran Canaria) } \\
\text { Perez-Gracia, Vega; Universitat Politècnica de Catalunya, Resistencia de } \\
\text { Materiales y Estructuras en la Ingeniería } \\
\text { Rodríguez-Santana, Carmen-Gloria; Museo y Parque Arqueológico Cueva } \\
\text { Pintada (Cabildo de Gran Canaria) }\end{array}$ \\
\hline Keywords: & $\begin{array}{l}\text { GPR, Laser Vibration, Painted Cave, Cueva Pintada, Amplification, } \\
\text { Detachment }\end{array}$ \\
\hline
\end{tabular}

\section{SCHOLARONE ${ }^{\text {IM }}$ Manuscripts}




\section{INTEGRATED GPR AND LASER VIBRATION SURVEYS TO PRESERVE \\ PREHISTORICAL PAINTED CAVES: CUEVA PINTADA CASE STUDY}

J.O. Caselles ${ }^{\mathrm{a}}$, J. Clapés ${ }^{1 a}$, J.I. Sáenz Sagasti ${ }^{\text {, V V. Pérez Gracia }}{ }^{\mathrm{c}}$ and C.G. Rodríguez Santana ${ }^{\mathrm{d}}$

${ }^{a}$ DECA. Universtat Politècnica de Catalunya. c/ Jordi Girona 1. 08034 Barcelona. Spain

b Museo y Parque Arqueológico Cueva Pintada. Spain

${ }^{c}$ Department of Strength of Materials and Structural Engineering (RMEE), Polytechnic University of Catalonia (BarcelonaTech), Barcelona, Spain

Correspondence : J.O. Caselles, DECA. Universitat Politècnica de Catalunya. c/ Jordi Girona 1. 08034 Barcelona. Spain. Email: oriol.caselles@upc.edu 


\begin{abstract}
The study of structural safety when it is covered by important paintings require a careful analysis without affecting the paintings. Therefore, non-destructive surveys are the only feasible method to obtain data about its state. In Cueva Pintada case, the problem requires a detailed but noninvasive analysis because this cave was dug in volcanic tuff. The tuff present poor consolidation. This geological material is very sensitive to vibration. Furthermore, the proximity to the city downtown increases vibrations due to traffic. Recently, a small rock fall produces damage and alerted of the cave state of conservation.

The painting walls constraint many of the NDT surveys. Two methodologies have been applied: ground-penetrating radar (GPR) and passive seismic. GPR analysis allowed determining the inner structure of the tuff cave, and results were used to determine the zones that required a wider and dense vibration study. Radar images shown important anomalies at depths of about $0.2 \mathrm{~m}$ to 0.8 meters and from 1.5 meters to the top of the roof, almost horizontal. Amplification factor measured by passive seismic survey range from 0.03 to 93 with near half of the ceil with amplifications higher than 5 and about $10 \%$ with amplifications over 50 times.
\end{abstract}

Keywords: GPR; Laser Vibration; Painted Cave; Cueva Pintada; Amplification, Detachment.

\title{
Introduction
}

Cueva Pintada is part of a huge complex of artificial caves, located near Galdar, in Northwest Gran Canaria Island. This cave was excavated in volcanic tuff and belonged to a Pre- 
Hispanic village. The most remarkable feature of this cave is the existence of geometrical wall paintings covering the walls (Fig. 1a). These paintings present triangles, rectangles, circles and squares, combining red, black and white colours. The archaeological space of the Cueva Pintada constitutes a key reference point in the study of the pre-Hispanic world of Gran Canaria. The cave presents approximately a cubic $3 \mathrm{~m}$ height shape. The length of the back wall is $5 \mathrm{~m}$, and the length of the lateral walls are $4.53 \mathrm{~m}$ and $4.26 \mathrm{~m}$.

During the 19th century, the increase in construction and farming brought to find many aboriginal remains and, being discovered Cueva Pintda as a result of the reform of an orchard in 1862. The archaeological works undertaken over more than two decades confirmed that the village was occupied from the 7 th to the 16 th centuries, being the last periods the best documented because archaeological discoveries are complemented with valuable written information (including travel writing, conquest chronicles and legal documents). Although, it is possible that the use of the cave and old constructions have been changed over time, we know that when the man-made cave was discovered, mummies, pottery and other archaeological objects were found. This fact suggests the space was probably designed for the celebration of offerings and ceremonies related to the dead.

In 1972, the set of caves wre opened to the public after deep studies. Unfortunately, the deterioration of the paintings led to the closure of the Cueva Pintada in 1982, and the subsequent creation of a complete plan focused in the preservation of the pre-Hispanic legacy. As a result of this project, begun in 1986, the modern Museum and Archaeological Park Cueva Pintada (Fig. 1b) was inaugurated on the 26th July, 2006.

The pre-Hispanic ruins in this area were covered by the soil that was placed and distributed by the man in order to create farming terraces. Excavations indicate that the ruins belong to a hamlet organized around the group of man-made caves, known as the Troglodyte Complex. 
The decorated chamber, known as Cueva Pintada, was in the center of the hamlet (Figure 1a). The agricultural landscape gradually disappeared as the excavations, begun in 1987, progressively brought to light the indigenous remains, and revealed a new archaeological space.

The excavations during this long period have allowed discover and recover innumerable archaeological remains. These findings have been of great importance to understand the context of the aboriginal cultures of the Canary Islands. Other findings are probably imported from the continent. The discovered objects during the excavations include several ceramic pots elaborated in potter wheels and metal objects such as coins, swords, knives, horseshoes, thimbles, nails, etc. The current aspect of the Troglodyte complex, according to the available archaeological data, was most likely achieve after the 12th century, belonging the painted panel of the cave to this period.

The study of the paintings indicates that the coloring agents are of mineral origin: oxidized clays for ochre and red and, fine whitened clays for the white. Both were mixed with water to make their application easier. The black color was not a pigment but a natural darkening of the tuff.

Currently, a triaxial accelerometer placed in one of the Troglodyte rooms, close to the painted cave constantly monitored Cueva Pintada (Soler at al., 2007). This supervising system was installed with the objective of monitoring the vibrations produced during the construction of the new museum. Nowadays, this system alert of strong vibrations. However, at beginning of 2016, a slight sand detachment inside the cave occurred without any important recorded vibration. That detachment forced to a wide study in order to determine possible causes and to preserve the complex, preventing further detachments. Part of the study included a detailed 
amplification vibration study. Before the vibration analysis, a high-resolution 3D GPR study was used to calculate the best places to determine the amplification at each point of the cover.

Ground Penetrating Radar has been extensively used in a large number of archeological sites (e.g., Zaho et al., 2013; Perez-Gracia et al. 2012; Perez-Gracia et al., 2009; Whiting et al., 2001; Perez-Gracia et al., 2000) and cultural heritage structures (e.g., Perez-Gracia, 2013; Cataldo, 2005; Ranalli et al., 2004). The archaeological studies were usually focused on detecting and mapping buried structures (e.g., Nuzzo et al., 2002; Sternberg and McGill, 1995), on analyzing the extension of the archaeological site or even on evaluating characteristics of the GPR received signal in order to correlate them with different archaeological features (Zhao et al. 2015; Zhao et al. 2013). Archaeological applications are based in many cases in 3D analysis by obtaining slices at different depths. The Cultural Heritage assessment use to be centered in the detection of pathologies in the structures such as moisture, cracks and detachmens (e.g., Cataldo et al., 2005; Ferrara and Barone, 2015; Santos-Assunçao et al., 2014; Perez-Gracia et al., 2013; Solla et al., 2011). In some cases, these studies are also applied to underground man-made structures (Santos-Assunçao et al., 2016) or to locate unknown constructive elements or other buried structures (Perez-Gracia et al., 2009a; Perez-Gracia et al., 2009b; Gonzalez-Drigo et al., 2008). However, GPR studies has been applied in few occasions in the study of rock caves and, in almost all the few cases, mainly focused in detecting or mapping the cavities (e.g., Čeru et al., 2018; Zhao et al., 2012; Beres et al., 2001) and in a minor number of cases, in the searching for buried archaeological targets in caves (Porsani et al., 2010). The main difficult in the use of GPR inside caves leads in two factors: the clutter and the irregular surface. Clutter is usually produced as consequence of reflections on the walls and roofs close to the antenna, and obscures the records because the external anomalies are superimposed to the anomalies produced by the 
reflections on the subsurface features. The irregular surface habitual in many caves complicates the radar data acquisition and introduces noise in the radargrams.

Laser vibrometer has been used in art diagnostic applications (i.e. Castellini et al, 1996 and 2003; Borri and Grazini, 2006; Quagliarini et al., 2013). In all cases, the artworks have been excited by some actuator or loudspeakers with white noise. The ambient noise is similar to a white noise (Caselles et al., 2018). Laser vibrometer has been also applied to civil engineering (p.e. Fukusda et al., 2010; Siringoringo and Fujino, 2009; Waldron et al., 2002) and in mining engineering (p.e., Swanson, 2002). Frequencies amplified in some loose roof rock in mines range from 200 to $1000 \mathrm{~Hz}$ (Summerfield, 1956; de Montille and Weber, 1971; Palmer and Czirr, 1982; Hanson, 1985). In general, mines have a very hard rocks compared with the volcanic stuff of Galdar. Pyroclastic materials can present shear velocities less than $200 \mathrm{~m} / \mathrm{s}$ (Nunziata et al., 1999).

Both geophysical surveys were used in the assessment of Cueva Pintada. GPR data and a careful visual inspection determined the points to be surveyed using vibrations, based on mapping the damage in the cave.

\section{Geological setting}

Cueva Pintada is located less than 500 meters from the Galdar volcano. This volcano is of Stromboli type, so pyroclastic materials compose the ground in an area of about $1.9 \mathrm{~km}^{2}$. In the Cueva Pintada zone, the soil structure presents several layers of pyroclastic materials with some degree of cementation. The thickness of these layers is variable, from $1.5 \mathrm{~m}$ thick to few centimeters in the case of the shallower ones. This structure is named volcanic tuff. The 
layers have a mainly horizontal stratigraphy, with a slope of less than $5 \%$. Sediments of variable thickness are the shallowest layer over the tuff. This layer is compose by materials from the erosion of the upper part of the volcanic structure. In some places, a carbonated centimeter layer, originated by organic soil, covers the surface. Thin layers of about 10 to 40 centimeters are intercalated with millimetric layers form the volcanic tuff of Cueva Pintada complex (Cañaveras et al., 2007). This milimetric layers or sheets are formed by the erosion of the surrounding layers and, in some of them, appear clays. Sometimes carbonates cement these layers. This sandwich structure is easily to be appreciated due to the color change and the differential erosion (Fig 1a.). In fact, each thin layer can by subdivided in thinnest layers due the differential deposition of the pyroclastic materials during the eruption.

The dissolution of tuff silicates into the water seeping through tuff pores produces the carbonate cement. Tuff presents high porosity and, although the rainfall is very low (less than $200 \mathrm{~mm}$ per year), the effects of water are clearly visible in the complex of troglodyte caves. One of the causes was the existence of farms placed on the soil over the troglodyte caves complex, previous to the construction of the museum. Fertilized water irrigates the crop of the farm. This fact produces a double effect; in one hand, there were more water circulating and, in the other hand the fertilizer produces, in some places, efflorescences. The chemical alteration index of Nesbitt and Young $(1982,1989)$ measured at the troglodyte complex are between moderated to moderated-high (Hoyos et al., 1998). The variability of the results of all tests performed at some test-tube extracted from the complex and a near curry is high. As a result, materials of the Cueva Pintada complex present an important weathering with detachment of little bits of tuff. 


\section{GPR survey}

Nine radar lines were carried out with a $900 \mathrm{MHz}$ center frequency antenna, on the roof of Cueva Pintada separated about 0.5 meters (Fig.2) covering the whole of the natural cover. Six of them with a length of about 5.1 meters, Two profiles of 4.9 meters and one of them of about 4.6 meters length. The position of the antenna was assured by an odometer placed in a little trolley down a stick, where the antenna was placed (Fig. 3). The length of the stick was variable in order to assure a distance between the antenna and the roof as little as possible without touching it.

Data was acquired with a $60 \mathrm{~ns}$ time window. Data processing consists of the application of a band pass frequency filter with cutoff frequencies of $225 \mathrm{MHz}$ and $1800 \mathrm{MHz}$.

\section{Vibration survey}

Vibration survey was carried out by means of an accelerometer and a laser Doppler system in order to not damage the cave and its paintings. The accelerometer was a piezoelectric one of B\&K 394A10 with flat response from 0.1 to up to $1300 \mathrm{HZ}$ and the Doppler system by a laser Doppler vibrometer PDV100 of Polytec. This is a system based on a Helium-Neon laser with an output power less than $1 \mathrm{~mW}$ (class 2) with a frequency range from 0.05 to $22 \mathrm{kHz}$. The wavelength is $633 \mathrm{~nm}$. This type of LASER is used in heritage conservation without damage for paintings (i.e. Castellini et al, 1996 and 2003). Some applications of Laser Doppler Vibrometer (LDV) use a force engine to produce and input vibration to be compared with the output vibration of each point. In our case, the use of a force engine to produce a vibration of the cave was not possible due to the dimension of the site and its special sensitivity to vibrations. For this reason, an accelerometer was placed on the starting point of 
the cave roof (covering shelter) in order of have a reference point. An overall peak hold analysis was used to detect the places where amplification of the vibration were produced.

The visual inspection detected cracks, and the layer structure in a centimeter dimension. Therefore, the required accuracy of the results might be on the same order. The long record time required to perform an overall peak analysis with natural vibration excitation make impossible to measure in all points with a centimeter accuracy. Using GPR results and the observed cracks in the natural roof of the cave, we plan the location of 118 measuring points (Fig. 4) of 360 seconds of record.

Surface images were computed by nearest interpolation due to the high variation between closed points.

A concert is played some time in front of the cave. For this reason, an analysis of the vibration produced by the music equipment used for the concerts was done. Only the point 94 was used to measure possible affections of concert on the cave roof vibration levels. For this study, the overall peak hold analysis and a Fourier analyses has been computed.

\section{GPR results}

An average velocity of about $10 \mathrm{~cm} / \mathrm{ns}$ was estimated using the two-way travel time of the reflected wave on the upper part of the cave cover. The consequent dielectric constant is about 11, which corresponds to a high porous volcanic rock (Rust et al., 1999) that is according with the measured values, around $25 \%$, in some tests of the troglodyte complex (Hoyos et al., 1998).

Radar images shown important anomalies produced by reflections at a depths of about $0.2 \mathrm{~m}$ to 0.8 meters ( $2 \mathrm{~ns}$ to $8 \mathrm{~ns}$ ) and from 1.5 meters ( $15 \mathrm{~ns})$ to the top to the roof. These targets 
seem to present almost horizontal arrangement. Time slices (Fig. 5) indicate the existence of an important detachment that goes slowly deeper from right to left. Other anomalies could be associated to cracks. The analysis of the radar images indicates that the zones affected by inner damage and detachment are more that $50 \%$ of the total roof cave.

\section{Vibration results}

The ratio between overall peak measured in the cave ceiling and in the reference point has ranged between 0.03 and 91 (Fig. 6). Near half of the ceiling have amplifications over 5 times and a quarter of it over 25 times. There are 14 measured points with ratios greater than 50 . But also there are $35 \%$ under 1 and $5 \%$ under 0.1 . The surface image computed by nearest interpolation shows high variation of the amplification in close distances.

The rock fall zone was produced near the point 42 with an overall peak ratio of 74 , an important crack and a zone were radar has depicted an inner crack.

The maximum vibration on the reference point, at the roof, was only of $0.35 \mathrm{~mm} / \mathrm{s}$ but in the ceiling was about $5.6 \mathrm{~mm} / \mathrm{s}$. This last value was done with a low reference vibration of 0.062 $\mathrm{mm} / \mathrm{s}$ so the expected value reached when high reference vibration occurs could be of about $31 \mathrm{~mm} / \mathrm{s}$.

Results of average spectra in all the measured points show two main frequencies (around 10 and $15 \mathrm{~Hz}$ ) that probably correspond to modal modes of the ceil. In general, points with high amplification show higher amplification of these modal frequencies but also some of them show other peaks at higher frequencies (Fig. 7).

Results of the concert simulation show overall peak amplification similar to the detected with the ambient noise vibration. The vibration level at the reference point produced during the concert simulation $(4,09 \mathrm{e}-005 \mathrm{~m} / \mathrm{s})$ was a little less than the measured without concert 


\section{Conclusions}

Dielectric constant measured in the roof of the painted cave reveals that the porosity of its roof is high and similar to the obtained in some tests in the troglodyte complex. This characteristic of the materials could favor water leaks and, therefore, damage on the paintings of the troglodyte complex.

GPR survey reveals the existence of potential damaged zones covering more than the $50 \%$ of the surface of the roof. In addition, the images highlight the existence of important cracks. The analysis of the results denotes the position and the practically horizontal layout of the most important cracks. Radar data was used in the planning of the subsequent vibration survey. Zones with more anomalies associated to inner cracks were densely studied with passive seismic, using a higher number of vibration measurement points.

The surface image computed by nearest interpolation shows high variation of the amplification that is produced by the layer structure of the cave roof. There are some sheets that have high amplifications of ambient noise vibrations reaching 91 times. The ratio between overall peak measured in the cave ceiling and in the reference point has ranged 
between 0.03 and 91, near half of the ceiling have amplifications over 5 times and a quarter of it over 25 times. There are 14 measured points with ratios greater than 50. But also there are $35 \%$ under 1 and $5 \%$ under 0.1 . The surface image computed by nearest interpolation shows high variation of the amplification in close distances.

The rock fall zone was produced near the point 42 with an overall peak ratio of 74 , an important crack and a zone were radar has depicted an inner crack.

The maximum vibration on the reference point, at the roof, was only of $0.35 \mathrm{~mm} / \mathrm{s}$ but in the ceiling was about $5.6 \mathrm{~mm} / \mathrm{s}$. This last value was done with a low reference vibration of 0.062 $\mathrm{mm} / \mathrm{s}$ so; the expected value reached when high reference vibration occurs could be of about $31 \mathrm{~mm} / \mathrm{s}$.

These high amplifications measured in some zones of the cave roof recommend decreasing the ambient noise vibration as much as possible.

The music concerts not affect significantly the cave except for low record of some instruments as tuba, double bass, bass guitar and piano in the frequency range between 10 to $40 \mathrm{~Hz}$.

\section{Acknowledgment}

This research was partially funded by the Ministry of Economy and Competitiveness (MINECO) of the Spanish Government and by the European Regional Development Fund (FEDER) of the European Union (UE) through the project referenced as CGL2015-65913-P (MINECO/ FEDER, UE). 


\section{References}

Beres, M., Luetscher, M., Olivier, R., 2001. Integration of ground-penetrating radar and microgravimetric methods to map shallow caves. Journal of Applied Geophysics 46(4), 249262.

Borri, A., Grazini, A., 2006. Diagnostic analysis of the lesions and stability of Michelangelo's David. Journal of cultural heritage 7, 273-285.

Cañaveras Jimenez, J.C., Sanz Rubio, E, Sanchez Moral, S., Hoyos Gómez, M., 2007. Las alteraciones de los materiales volcánicos encajantes del complejo troglodíta de la Cueva Pintaada: ecología, petrología y geoquímica. Cuadernos de Patrimonio Histórico 7. 59-81.

Caselles, O., Clapes, J., Elyamani, A., Lana, J., Seguí, C., Martín, A., Roca, P., 2018.

Damage detection using principal component analysis applied to temporal variation of natural frequencies. In: Proceedings of the $16^{\text {th }}$ European Conference on Earthquake Engineering. Thessalonica, Greece.

Castellini, P., Paone, N., Tomasini, E.P., 1996. The laser doppler vibrometer as an instrument for nonintrusive diagnostic of works of art: Application to fresco paintings. Optics and lasers in engineering $25,227-246$.

Castellini, P., Esposito, E., Marchetti, B., Paone, N., Tomasini, E.P., 2003. New applications of scanning laser doppler vibrometer (SLDV) to non-destructive diagnostic of artworks: mosaics, ceramics, inlaid wood and easel painting. Journal of cultural heritage 4, 321-329.

Cataldo, R., De Donno, A., De Nunzio, G., Leucci, G., Nuzzo, L., Siviero, S., 2005. Integrated methods for analysis of deterioration of cultural heritage: the Crypt of "Cattedrale di Otranto". Journal of cultural heritage 6(1), 29-38. 
Čeru, T., Šegina, E., Knez, M., Benac, С̌., Gosar, A., 2018. Detecting and characterizing unroofed caves by ground penetrating radar. Geomorphology 303, 524-539.

Ferrara, C., Barone, P. M., 2015. Detecting moisture damage in archaeology and cultural heritage sites using the GPR technique: a brief introduction. International Journal of Archaeology 3(1-1), 57-61.

Fukuda,Y., Feng, M.Q., Shiunozuka, M., 2010. Cost-effective vision-based system for monitoring dynamic response of civil engineering structures. Structural Control and Health Monitoring 17, 918-936.

González-Drigo, R., Pérez-Gracia, V., Di Capua, D., Pujades, L. G., 2008. GPR survey applied to Modernista buildings in Barcelona: The cultural heritage of the College of Industrial Engineering. Journal of Cultural Heritage 9(2), 196-202.

Gracia, V. P., Canas, J. A., Pujades, L. G., Clapés, J., Caselles, O., Garcıa, F., Osorio, R., 2000. GPR survey to confirm the location of ancient structures under the Valencian Cathedral (Spain). Journal of Applied Geophysics 43(2-4), 167-174.

Hoyos Gómez, M., Sanchez Moral, S., Sanz Rubio, E., Cañaveras Jimenez, J.C., 1998. Informe sobre la alteración de los materiales volcánicos encajantes del complejo troglodita de Galdar (Gran Canaria). CSIC, Madrid.

Nesbitt, H.W., Young, G.M., 1982. Early proterozoic climates and plate motion inferred from major element chemistry of lutites. Nature, 299, 715-717.

Nesbitt, H.W., Young, G.M., 1989. Formation and diagnesis of weathering profiles. Journal of Geology 97, 129-147.

Nunziata, C., Mele, R., Natale, M.. 1999. Shear wave velocities and primary influencing factors of Campi Flegrei-Neapolitan deposits. Engineering Geology 54, 299-312 
Nuzzo, L., Leucci, G., Negri, S., Carrozzo, M. T., Quarta, T., 2002. Application of 3D visualization techniques in the analysis of GPR data for archaeology. Annals of Geophysics $45(2)$.

Pérez-Gracia, V., Caselles, J. O., Clapes, J., Osorio, R., Martínez, G., Canas, J. A., 2009a. Integrated near-surface geophysical survey of the Cathedral of Mallorca. Journal of Archaeological Science 36(7), 1289-1299.

Pérez-Gracia, V., Caselles, O., Clapés, J., Osorio, R., Canas, J. A., Pujades, L. G., 2009 b. Radar exploration applied to historical buildings: a case study of the Marques de Llió palace, in Barcelona (Spain). Engineering Failure Analysis 16(4), 1039-1050.

Pérez-Gracia, V., González-Drigo, R., Sala, R., 2012. Ground-penetrating radar resolution in cultural heritage applications. Near Surface Geophysics $10\left({ }^{\circ} 1\right), 77-87$.

Pérez-Gracia, V., Caselles, J. O., Clapés, J., Martinez, G., Osorio, R., 2013. Non-destructive analysis in cultural heritage buildings: Evaluating the Mallorca cathedral supporting structures. NDT \& E International 59, 40-47.

Porsani, J. L., de Matos Jangelme, G., Kipnis, R., 2010. GPR survey at Lapa do Santo archaeological site, Lagoa Santa karstic region, Minas Gerais state, Brazil. Journal of archaeological science 37(6), 1141-1148.

Quagliarini, E., Esposito, E., del Conte, A., 2013. The combined use of IRT and LDV for the investigation of historical thin vaults. Journal of cultural heritage 14, 122-128.

Doi:10.1016/j.culher.2012.01.004

Ranalli, D., Scozzafava, M., Tallini, M., 2004. Ground penetrating radar investigations for the restoration of historic buildings: the case study of the Collemaggio Basilica (L'Aquila, Italy). Journal of cultural heritage 5(1), 91-99. 
Rust, A.C., Rusell, J.K., Kgnight, R.J., 1999. Dielectric constant as a predictor of porosity in dry volcanic rocks. Journal of volcanology and geothermal research 91, 76-96.

Santos-Assunçao, S., Perez-Gracia, V., Caselles, O., Clapes, J., Salinas, V., 2014.

Assessment of complex masonry structures with GPR compared to other non-destructive testing studies. Remote Sensing 6(9), 8220-8237.

Santos-Assunçao, S., Dimitriadis, K., Konstantakis, Y., Perez-Gracia, V., Anagnostopoulou, E., Gonzalez-Drigo, R., 2016. Ground-penetrating radar evaluation of the ancient Mycenaean monument Tholos Acharnon tomb. Near Surface Geophysics 14(2), 197-205.

Siringoringo, D.M., Fujino, Y., 2009. Noncontact operational modal analysis of structural members by laser doppler vibrometer. Computer-Aided Civil and Infrastructure Engineering $24,249-265$.

Soler Javaloyes, V., Torres González, P.A., Moure García, A.P., 2007. Registro de vibraciones y análisis del fondo sísmico en el entorno de la Cueva Pintada de Gáldar. Cuadernos de Patrimonio Histórico 7, 125-132.

Solla, M., Lorenzo, H., Rial, F. I., Novo, A., 2011. GPR evaluation of the Roman masonry arch bridge of Lugo (Spain). NDT \& E International 44(1), 8-12.

Sternberg, B. K., McGill, J. W., 1995. Archaeology studies in southern Arizona using ground penetrating radar. Journal of Applied Geophysics 33(1-3), 209-225.

Swanson, P., 2002. Feasibility of using laser-based vibration measurements to detect roof fall hazard in underground mines. In: Proceedings of the $5^{\text {th }}$ Int. Conf. on Vibration Measurements by Laser Techniques. Ancoma, Italy 
Waldron, K., Ghoshal, A., Schulz, M. J., Sundaresan, M. J.,Ferguson, F., Pai, P. F.. Chung, J. H., 2002. Damage detection using finite element and laser operational deflection shapes, Finite Elements in Analysis and Design 38(3), 193-226.

Whiting, B. M., McFarland, D. P., Hackenberger, S., 2001. Three-dimensional GPR study of a prehistoric site in Barbados, West Indies. Journal of Applied Geophysics 47(3-4), 217-226. Zarandieta, L., Sosa, J.M., Feduchi J., 2007. El proyecto arquitectónico del museo y parque arqueológico de la Cueva Pintada: Una intervención para la conservación Cuadernos de Patrimonio Histórico 7. 219-251

Zhao, W., Forte, E., Pipan, M., Tian, G., 2013. Ground penetrating radar (GPR) attribute analysis for archaeological prospection. Journal of Applied Geophysics 97, 107-117.

Zhao, W., Forte, E., Levi, S. T., Pipan, M.,Tian, G., 2015. Improved high-resolution GPR imaging and characterization of prehistoric archaeological features by means of attribute analysis. Journal of Archaeological Science 54, 77-85. 


\section{FIGURE CAPTION}

Figure 1. Cueva Pintada. a) The sandwitched layer structure is appreciated in the walls and in the roof. b) Outside view of the museum complex designed as a typical Canarian greenhouse remembering the old use of the emplacement (Zarandieta et al., 2007). c) Maps of the location.

Figure 2. Map of the painted cave with the location of the radargram (straight lines marked with R1 to R9), rock fall produced at begin of 2016 (cercle), the natural cave (black line) and reinforced concrete cover (red line).

Figure 3. Photography of the trolley developed to carry out the GPR survey.

Figure 4. Location of the planned measuring points. In red the zones where GPR has detected inner cracks.

Figure 5. 3D GPR images.

Figure 6. Overall peak ratio of the cave ceiling. In grey main surface cracks. Black circle marks the rock fall zone of 2016. 
Figure 7. Autospectra of LASER vibrometer in different places.

Figure 8. Autospectra of fixed accelerometer (continuous line) and LASER vibrometer (dashed line) at reference point 94 during simulation concert (dark lines) and without simulation concert (gray lines). 

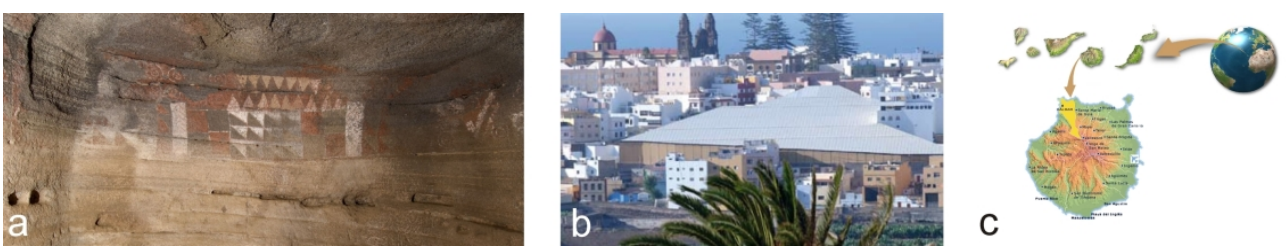

Figure 1. Cueva Pintada. a) The sandwitched layer structure is appreciated in the walls and in the roof. b) Outside view of the museum complex designed as a typical Canarian greenhouse remembering the old use of the emplacement (Zarandieta et al., 2007). c) Maps of the location.

$$
280 \times 49 \mathrm{~mm}(300 \times 300 \mathrm{DPI})
$$




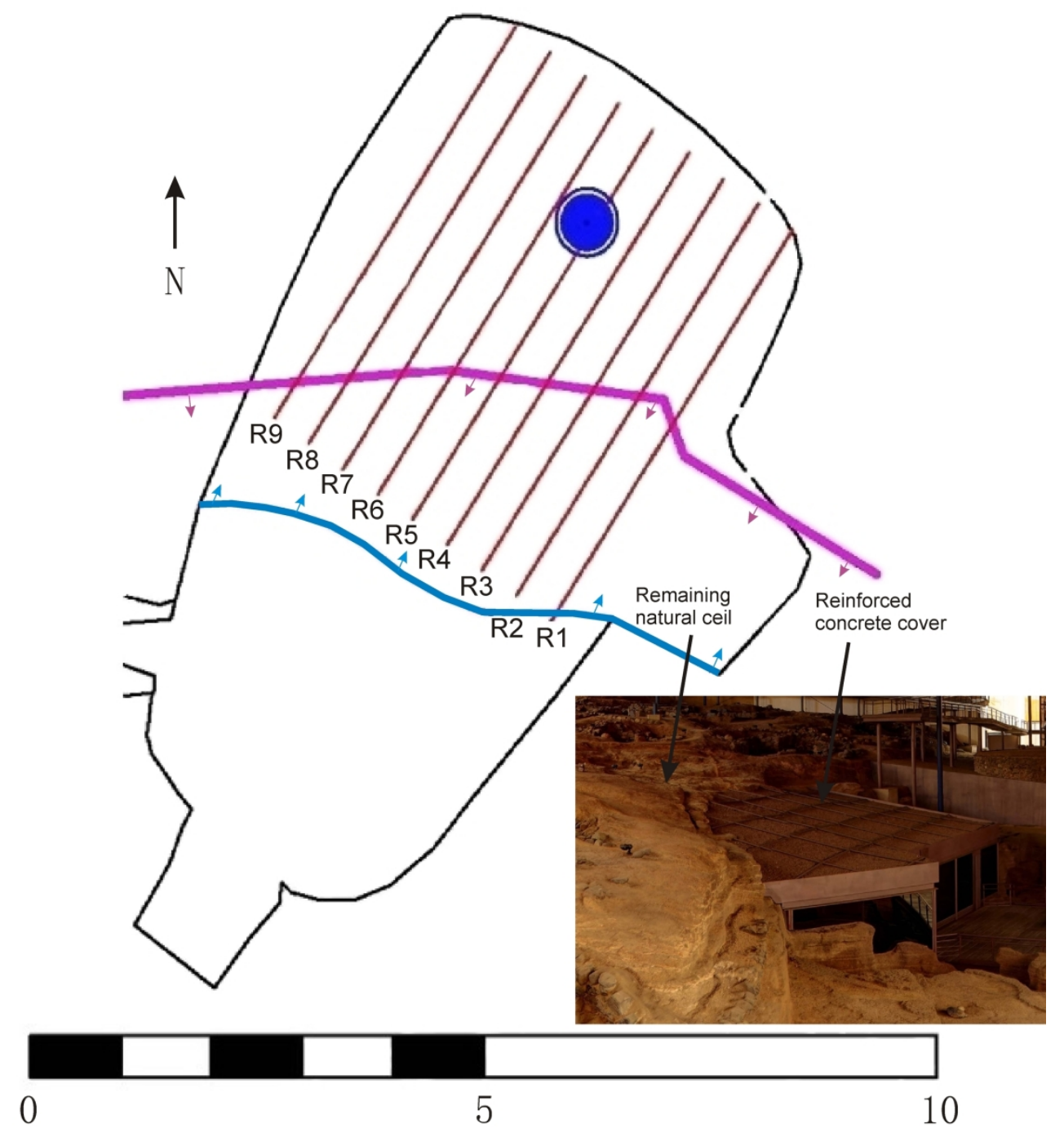

Figure 2. Map of the painted cave with the location of the radargram (straight lines marked with R1 to R9), rock fall produced at begin of 2016 (cercle), the natural cave (black line) and reinforced concrete cover (red line).

$224 \times 257 \mathrm{~mm}(300 \times 300 \mathrm{DPI})$ 


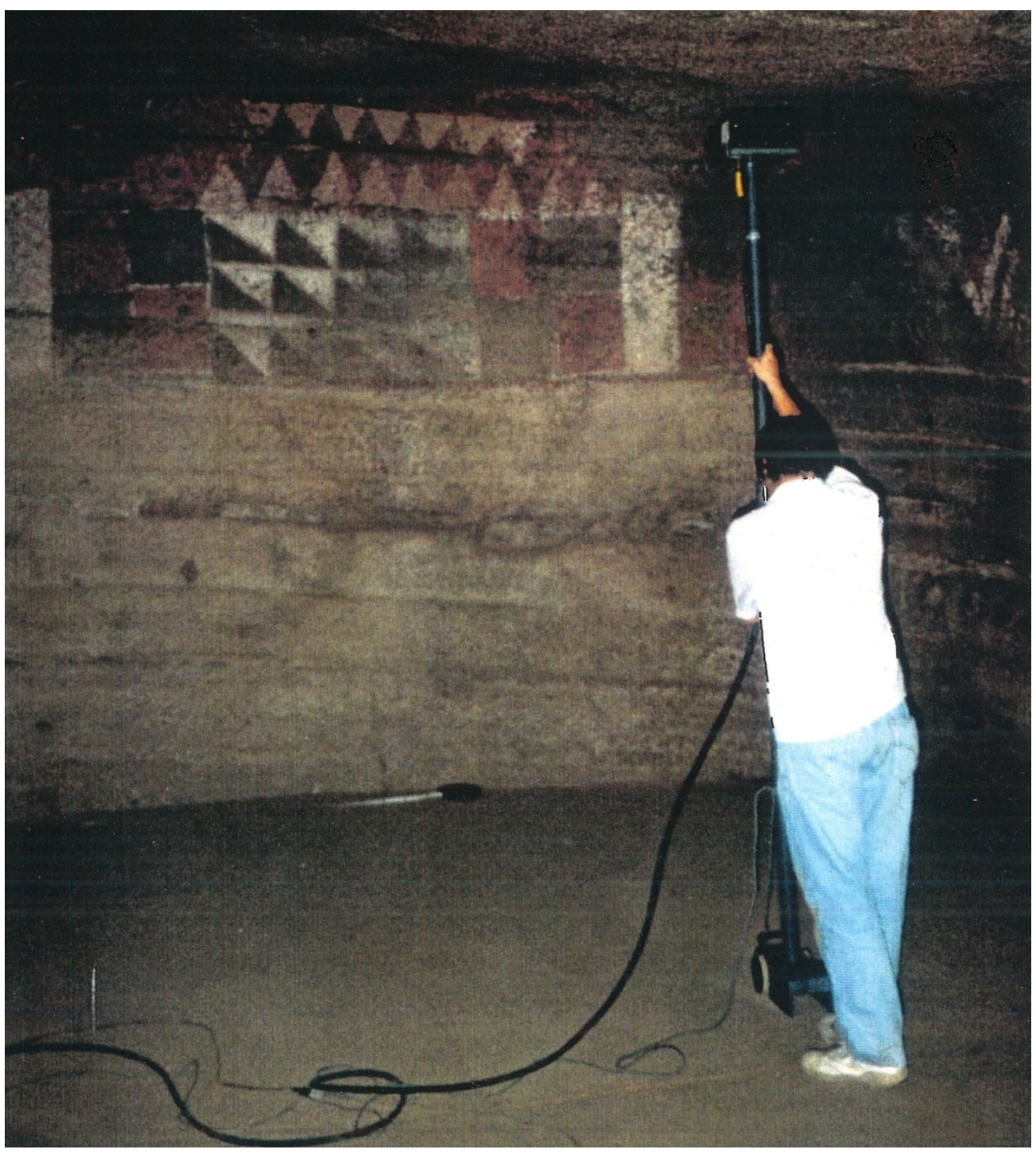

Figure 3. Photography of the trolley developed to carry out the GPR survey. $602 \times 668 \mathrm{~mm}(96 \times 96 \mathrm{DPI})$ 
Figure 4. Location of the planned measuring points. In red the zones where GPR has detected inner cracks. $243 \times 231 \mathrm{~mm}(87 \times 87 \mathrm{DPI})$ 


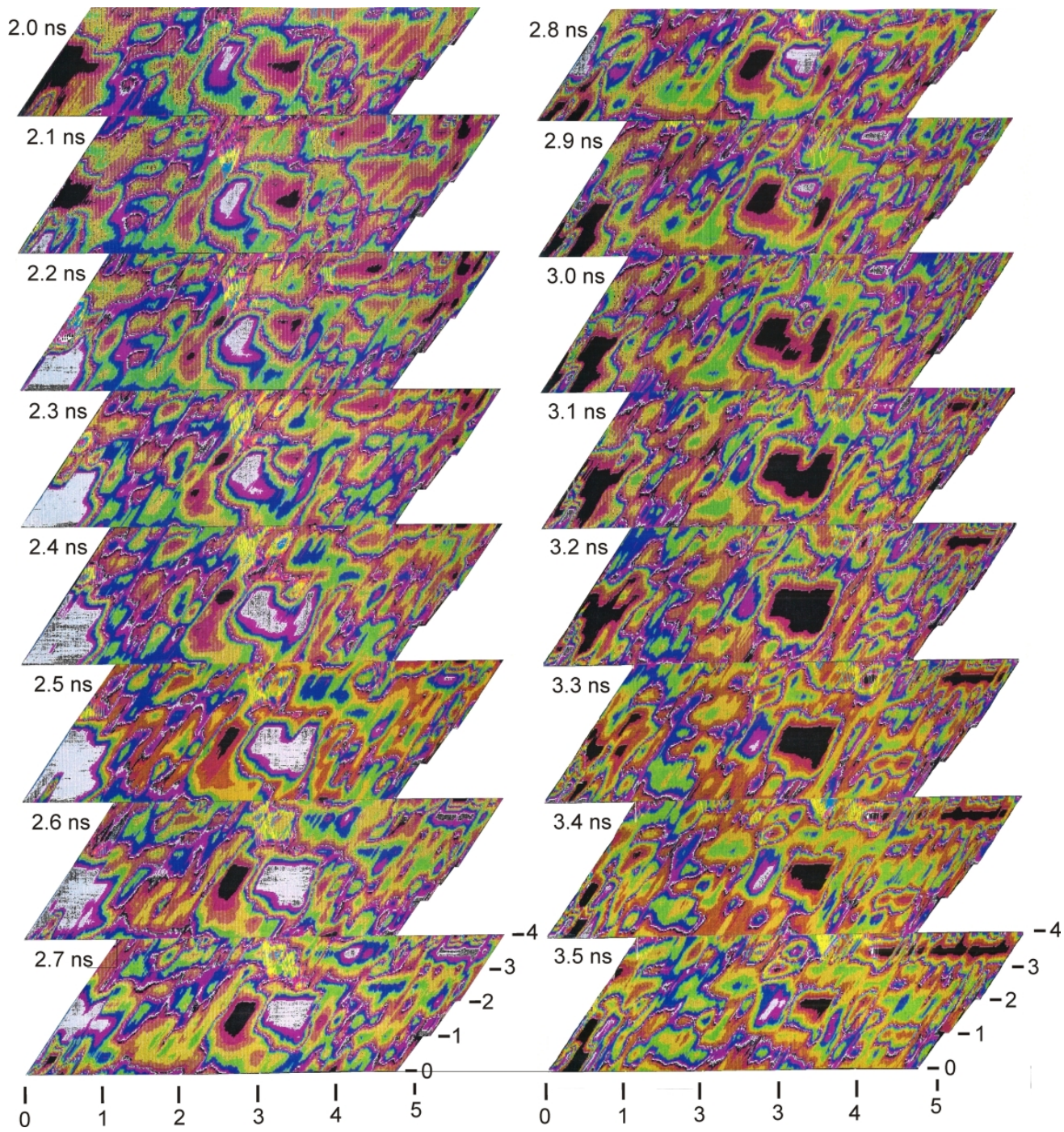

Figure 5. 3D GPR images.

$275 \times 293 \mathrm{~mm}(300 \times 300$ DPI $)$ 

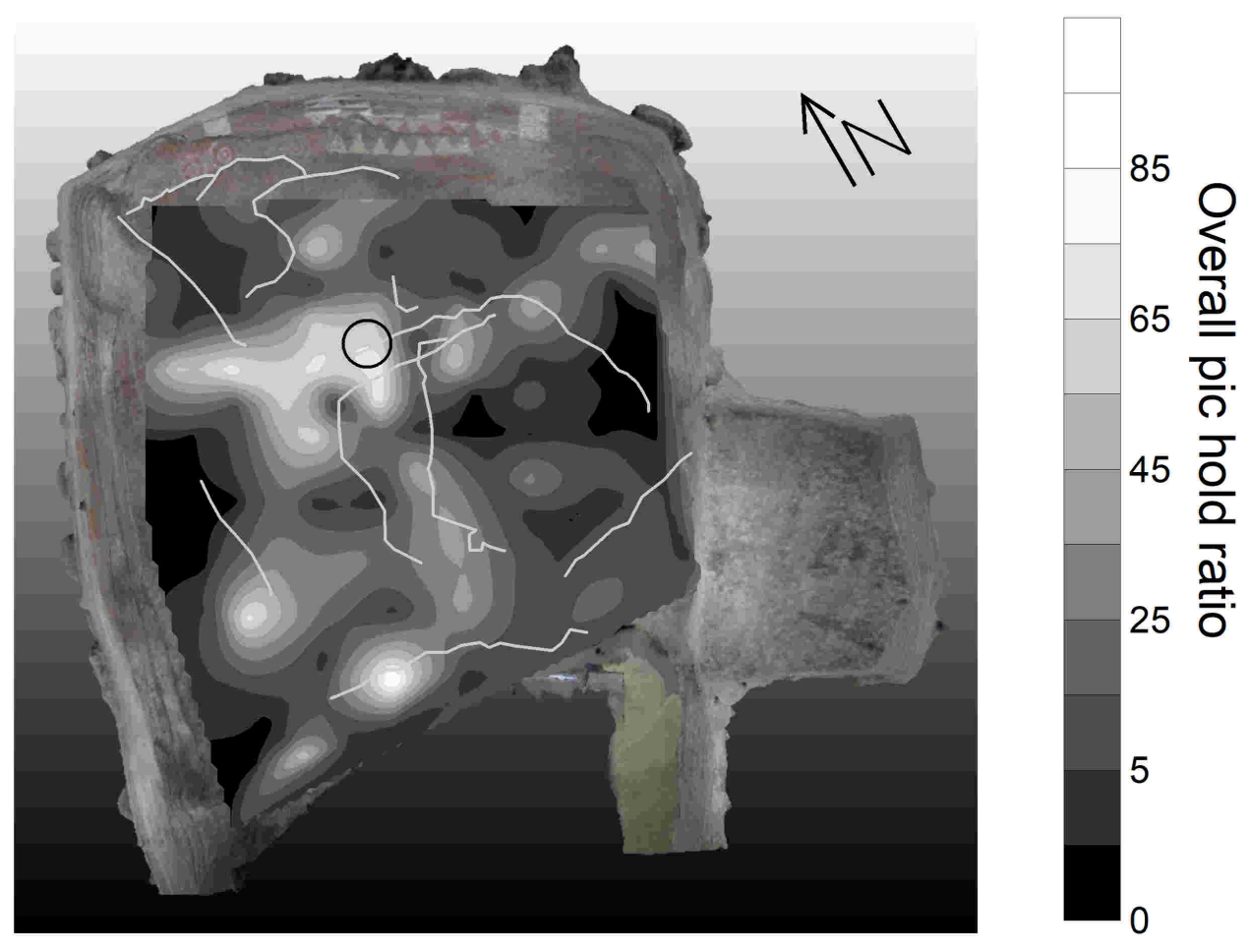

Figure 6. Overall pic ratio of the cave ceiling. In grey main surface cracks. Black circle marks the landslide zone of 2016.

\section{$694 \times 574 \mathrm{~mm}(93 \times 93 \mathrm{DPI})$}


10

11

12

13

14

15

16

17

18

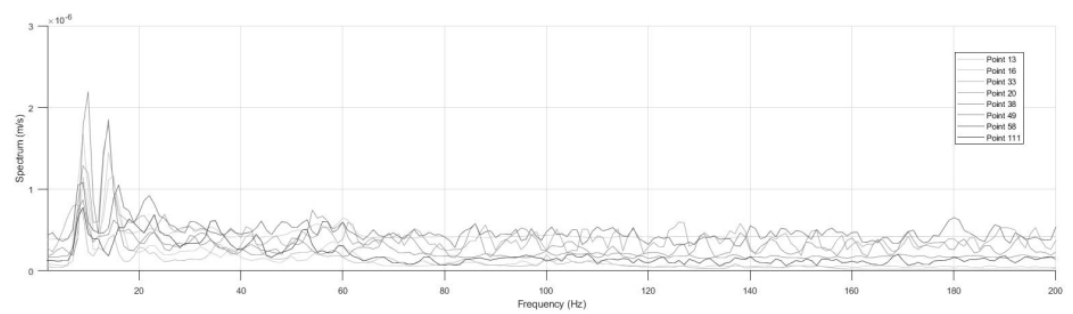

Figure 7. Autospectra of LASER vibrometer in different places.

$677 \times 255 \mathrm{~mm}(72 \times 72 \mathrm{DPI})$ 
Figure 8. Autospectra of fixed accelerometer (continuous line) and LASER vibrometer (dashed line) at reference point 94 during simulation concert (dark lines) and without simulation concert (gray lines).

$340 \times 91 \mathrm{~mm}(120 \times 120 \mathrm{DPI})$ 